\title{
RENAL TUBULAR DAMAGE IN INFANTILE GASTRO-ENTERITIS
}

\author{
BY \\ JOHN BLACK \\ From The Hospital for Sick Children, Great Ormond Street, London
}

(RECEIVED FOR PUBLICATION AUGUST 17, 1958)

\section{Introduction}

The natural history of acute tubular necrosis in adults has been well documented, but accounts of the condition in infants and children are rare. Most of the descriptions of tubular necrosis in the paediatric literature refer to older children (Riddell, 1951 ; Kaplan and Fomon, 1953; Wagner, 1954), but Pratt (1948) described two cases due to sulphonamides, aged 10 months and 18 months, and Jonsson (1951) published three fatal cases of severe asphyxia neonatorum with oliguria and raised blood urea, but at autopsy in Jonsson's cases there were haemoglobin casts in the distal tubules with no degeneration of the tubular epithelium. Doxiadis (1947) described tubular changes in some fatal cases of gastro-enteritis, but the details of the renal histology given are insufficient to make it clear whether he was dealing with acute tubular necrosis or with some type of nephrocalcinosis. The pathological aspect of renal disorders in early life associated with circulatory disturbances has been fully reviewed by Zuelzer, Charles, Kurnetz, Newton and Fallon (1951) who showed that various types of acute renal failure not uncommonly develop in severely dehydrated children. They described a range of vascular complications affecting the kidney, including 'lower nephron nephrosis' (acute tubular necrosis). In many of their cases diarrhoea and vomiting appeared to have been the precipitating symptoms. Carré and Squire (1956) published three cases of anuria with tubular necrosis, which were studied in great detail. The cause of the anuria was uncertain in the first case, and was thought to be due to sulphonamides and a penicillin reaction respectively in the other two cases.

Recent work (Oliver, MacDowell and Tracy (1951) and Van Slyke (1954)) has indicated that, apart from certain poisons, renal ischaemia is the probable cause of most cases of acute tubular necrosis, and that the ischaemia is itself a response to certain circulatory disorders associated with severe shock. In children, acute gastro-enteritis is probably the commonest cause of dehydration and shock, and it is surprising that there have been no reports of the clinical recognition of tubular damage in this condition. The only observations on this subject are those of Calcagno and Rubin (1951) and of Kerpel-Fronius, Varga, Kun and Vönöczky (1954). Calcagno and Rubin (1951) produced evidence of failure of water reabsorption during the acute phase of dehydration and shock in two severe cases, but found that complete recovery occurred within 24 hours and five days respectively. KerpelFronius et al. (1954) stated that it was often some days or even weeks before complete restoration of renal function occurred.

Two cases with evidence of tubular damage are here reported in full, together with a retrospective survey showing that minor degrees of renal damage are not uncommon in gastro-enteritis.

\section{Case Reports}

Case 1 (G.B.). On December 19, 1950, an 18-monthold male child was admitted to hospital with a two-day history of severe diarrhoea and vomiting. He was comatose and very dehydrated (Table 1). There was slight stiffness of the neck and back, but the limbs were hypotonic.

TABLE 1

INVESTIGATIONS ON ADMISSION: CASE 1

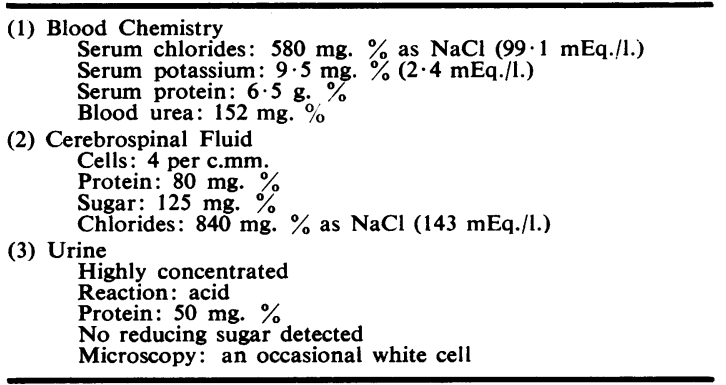


Progress and Treatment. Half-strength Hartmann's solution in $2 \frac{1}{2} \%$ glucose was given immediately, followed by half-strength plasma. There was a temporary improvement but by the third day he was still hypotonic and uninterested in his surroundings, though his hydration appeared quite normal. By the eighteenth day he seemed to have made a complete recovery from the gastro-enteritis and was discharged. On his return home his apathy did not improve, he was difficult to feed and did not speak. He was therefore readmitted for further investigation (Table 2).

TABLE 2

INVESTIGATIONS ON RE-ADMISSION: CASE 1 (13.1.51)

(1) Blood chemistry

Serum chlorides: $577 \mathrm{mg}$. \% as $\mathrm{NaCl}(98.7 \mathrm{mEq} . / \mathrm{l}$.)

Plasma bicarbonate: 37.5 vols. $\mathrm{CO}_{2} \%(16.7 \mathrm{mEq} . / 1$. Serum potassium: $16 \mathrm{mg} . \%(4 \cdot 2 \mathrm{mEq} . / 1$.

(2) Urine Blood urea: $23 \mathrm{mg}$. \%

Reaction: alkaline

Protein: $170 \mathrm{mg} . \%$

Microscopy: numerous epithelial cells

Progress During Second Admission. (Fig. 1.) There was now evidence of a bilateral pyramidal lesion probably due to thrombosis of the sagittal sinus. The blood chemistry showed a moderate acidosis with normal serum potassium and blood urea (Table 2). A few days later the serum potassium fell to $15.4 \mathrm{mg}$. $\%$ (3.9 mEq./1.) and then to $13.8 \mathrm{mg}$. \% (3.5 mEq./1.).

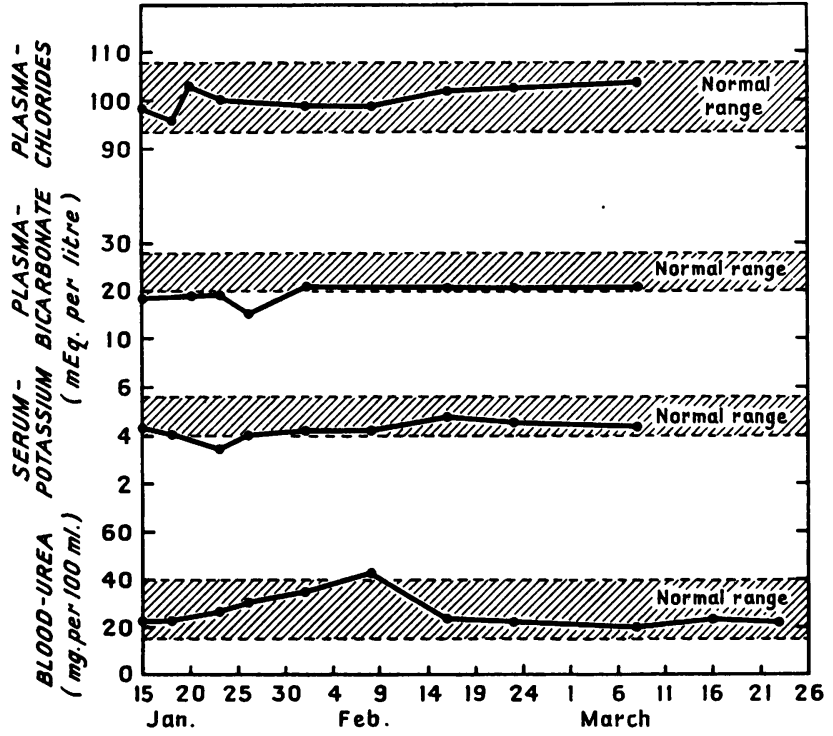

FIG. 1.-Case 1. Blood chemistry during second admission. A mild acidosis and transient hypokalaemia were found. With treatment, the blood chemistry became normal and remained normal after treatment was stopped.

As there was no diarrhoea to account for the acidosis the urine was investigated for evidence of a tubular defect causing failure of acidification of the urine. The urinary $p \mathrm{H}$ varied between 6.5 and a definitely alkaline reaction

TABLE 3

URINE TESTS: CASE 1

\begin{tabular}{|c|c|c|c|c|c|c|c|}
\hline Date & $\begin{array}{l}\text { Reaction } \\
\text { or } p \mathrm{H}\end{array}$ & $\begin{array}{l}\text { Specific } \\
\text { Gravity }\end{array}$ & $\underset{\text { (mg. \%) }}{\text { Urea }}$ & $\begin{array}{l}\text { Protein } \\
\text { (mg. \%) }\end{array}$ & Amino Acids & Deposit & Remarks \\
\hline 19.12 .50 & Acid & - & - & 50 & - & Occasional W.B.C. & \\
\hline 16. 1.51 & Alkaline & - & - & 170 & - & E.C.* ++ & \\
\hline 17. 1.51 & Neutral & - & - & 150 & - & E.C. ++ & \\
\hline 18.1 .51 & $6 \cdot 5$ & 'Dilute' & - & - & ++ & E.C. + & $\begin{array}{l}\begin{array}{l}\text { Slight reduction of Benedict's } \\
\text { solution. Acidotic }\end{array} \\
\end{array}$ \\
\hline $\begin{array}{ll}22 & 1.51 \\
\end{array}$ & Acid & - & - & 50 & - & E.C. + & \\
\hline 23. 1.51 & 6.49 & 1,027 & 2,900 & 0 & - & E.C. + & $\begin{array}{l}\text { After 12-hour fluid restriction. } \\
\text { Acidotic }\end{array}$ \\
\hline $23.4 .5 \mathrm{r}$ & $6 \cdot 47$ & 1,017 & 3,000 & Trace & $\begin{array}{l}\text { Slight increase } \\
\text { above normal }\end{array}$ & E.C. + & $\begin{array}{c}\text { Amino acids added to feeds. } \\
\text { Acidotic }\end{array}$ \\
\hline 24.1 .51 & Alkaline & 1,026 & - & 30 & - & Addis count normal & \\
\hline 27. 1.51 & $5 \cdot 7$ & 1,027 & 3,300 & Trace & - & - & $\mathrm{NH}_{3}$ coeff. $6.3 \%$ \\
\hline 29.1 .51 & - & - & - & - & - & - & $\begin{array}{c}\text { Slight reduction of Benedict's } \\
\text { solution }\end{array}$ \\
\hline 12. 2.51 & Alkaline & - & - & - & Normal & E.C. + & \\
\hline 19. 2.51 & $6 \cdot 07$ & - & - & - & + & . - & $\begin{array}{l}\text { Galactose } 10-15 \mathrm{mg} \% \\
\text { amino acids in feeds }\end{array}$ \\
\hline 5. 3.51 & - & - & - & 0 & - & $\begin{array}{c}\text { Occasional R.B C., } \\
\text { W.B.C., E.C. }\end{array}$ & \\
\hline 27. 3.51 & Acid & - & - & 0 & Normal & - & \\
\hline
\end{tabular}


(Table 3 ) in spite of the acidosis. On one occasion there was some reduction of Benedict's solution and chromatography of this specimen showed marked amino-aciduria. Amino-aciduria was found in a lesser amount five days later. Proteinuria was also present $(170 \mathrm{mg}$. \%) and this persisted for eight days. On microscopy a large number of epithelial cells was found.

Treatment was started with a sodium citrate-citric acid mixture (Albright's solution) and potassium chloride. The blood chemistry gradually returned to normal and remained normal when the alkali and potassium chloride were stopped after 36 days treatment.

By the fourteenth day after readmission the urine was quite normal apart from the persistence of epithelial cells on microscopy, and renal function appeared to have completely recovered, as shown by a specific gravity of 1,026 after a 12-hour fluid restriction (though there was no evidence of defective water reabsorption at any time). An Addis count and a combined inulin and urea clearance were also normal (Table 4).

TABLE 4

RENAL FUNCTION TESTS: CASE 1

\begin{tabular}{|c|c|c|c|}
\hline Date & Procedure & Result & Comment \\
\hline 23.1 .51 & $\begin{array}{l}\text { 12-hr. fluid re- } \\
\text { striction }\end{array}$ & S.G.: 1027 & $\begin{array}{l}\text { Normal } \\
\text { response }\end{array}$ \\
\hline 24.1 .51 & $\begin{array}{l}\text { Addis count } \\
\text { 12-hr. overnight } \\
\text { urine collection }\end{array}$ & $\begin{array}{l}\text { Volume: } 190 \mathrm{ml} . \\
\text { S.G.: } 1026 \\
\text { Protein: } 30 \mathrm{mg} . \% \\
\text { R.B.C.: } 114,000 \\
\text { W.B.C.: } 1,444,000 \\
\text { Casts: Nil }\end{array}$ & \\
\hline 25.1 .51 & $\begin{array}{l}\text { Combined urea } \\
\text { and inulin } \\
\text { clearance* }\end{array}$ & $\begin{array}{l}\text { Urea clearance } \\
\text { Period I: } 119 \% \dagger \\
\text { Period II : } 188 \% \dagger \\
\text { Period III: } 210 \% \dagger \\
\text { All maximum clearances } \\
\text { Inulin clearance } \\
\text { Period I: } 111 \mathrm{ml} . / \mathrm{min} \text {. } \\
\text { Period II: } 74 \mathrm{ml} . / \mathrm{min} \text {. } \\
\text { Normal for age: } 110 \mathrm{ml} . / \\
\text { min. } \\
\text { Surface area: } 0.51 \mathrm{sq} . \\
\text { metres }\end{array}$ & $\begin{array}{l}\text { Normal } \\
\text { Normal }\end{array}$ \\
\hline 19.2 .52 & Urea clearance* & $\begin{array}{l}\text { Case } 2 \\
\text { Single period ( } 4 \text { hours) } \\
94 \cdot 1 \% \text { average } \\
\text { Surface area: } 0 \cdot 30 \text { sq. } \\
\text { metres }\end{array}$ & $\begin{array}{l}\text { Normal } \\
\text { Normal }\end{array}$ \\
\hline
\end{tabular}

* Clearances have been recalculated as for a surface area of $1 \cdot 73$ sq. metres.

$\dagger$ Of average normal.

Comment. There was severe dehydration with azotaemia on admission, and it seems fairly certain that the cerebral damage was sustained at this time: this aspect of the case has been considered fully by Schlesinger and Welch (1952). The urine on admission showed nothing abnormal apart from a slight excess of protein, and renal damage was not suspected until the second admission. It is curious that no thirst or polyuria was noticed at any time and that the tubular damage apparently affected only the $\mathrm{H}$-ion exchange mechanism, and the reabsorption of amino acids and glucose. The exact significance of the proteinuria in terms of glomerular or tubular damage will be discussed later. That structural damage to the tubular epithelium did occur was confirmed by the large number of epithelial cells found in the urine. Recovery of renal function appeared to be complete.

\section{Case History}

Case 2 (G.A.). On January 27, 1952 a 12-week-old male infant was admitted to hospital from a residential nursery. No history of diarrhoea or vomiting could be obtained, but it was stated that he had not been taking his feeds well for some days. During his stay of three weeks in the nursery he had lost one pound in weight. On admission he was very shocked and dehydrated, with peripheral cyanosis. There was dyspnoea from gross abdominal distension. His lips and mouth were bilestained and he was vomiting spontaneously small quantities of bilious fluid. After rectal examination a small amount of bright yellow fluid faeces was passed. As there was no clinical or radiological evidence of an organic obstruction it was considered that he was suffering from gastro-enteritis with ileus, probably due to hypokalaemia. His blood chemistry (Table 5) confirmed this.

\section{TABLE 5}

\section{INVESTIGATIONS ON ADMISSION: CASE 2}

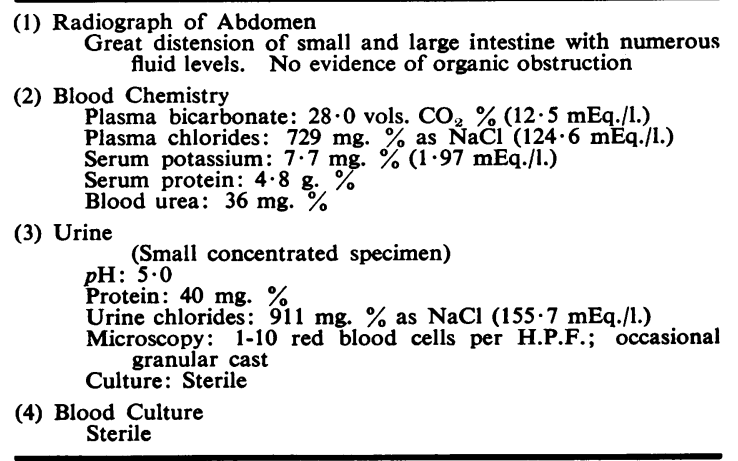

Progress and Treatment. Treatment was with continuous gastric suction and intravenous fluids, using half-strength Hartmann's solution in $2 \frac{1}{2} \%$ glucose. Later 1/6th $M$ sodium lactate was given with additional potassium chloride intravenously at first and then by mouth. Because of the persistent hypokalaemia (Fig. 2) the potassium chloride was continued till the seventeenth day. On the second day oedema developed and lasted for eight days. Vomiting persisted until the eleventh day, after which oral feeding was gradually established. The diarrhoea, however, continued for three weeks. Though gastric suction was necessary during the first five days the abdominal distension decreased gradually and had disappeared by the twelfth day. On the fifth day there was a deterioration in the child's condition and he appeared to be slightly dehydrated in spite of the oedema 
of the hands and feet. At the same time polyuria was noticed and there was a loss of $1 \mathrm{lb}$. in weight during the next 24 hours, with only a slight decrease in the oedema. In spite of the dehydration the urine was dilute. The fluid intake was therefore increased to $46 \mathrm{oz}$. $(1,288 \mathrm{ml}$.) daily in order to keep pace with the urinary losses. At this time also the haemoglobin was found to be $50 \%$ (Sahli), and a total of $125 \mathrm{ml}$. of blood was given in two transfusions. In view of the polyuria the urine and renal functions were investigated and definite evidence of renal tubular damage was found (see below).

Apart from one short episode of diarrhoea there was now a gradual improvement: the potassium chloride was stopped on the eighteenth day and oral feeding without intravenous supplements was established at the same time. Thereafter the feeds were increased and there was a gradual gain in weight. He was finally discharged after eight weeks in hospital. When seen again two months later he appeared well and had gained $2 \mathrm{lb} .4 \mathrm{oz}$. in weight.

Blood Chemistry. (Fig. 2.) On admission there was a severe acidosis with hyperchloraemia almost certainly due to diarrhoea, though this had apparently passed unnoticed. The blood urea on admission was normal (36 mg. \%) in spite of the gross dehydration; this may have been due to a very rapidly developing dehydration.

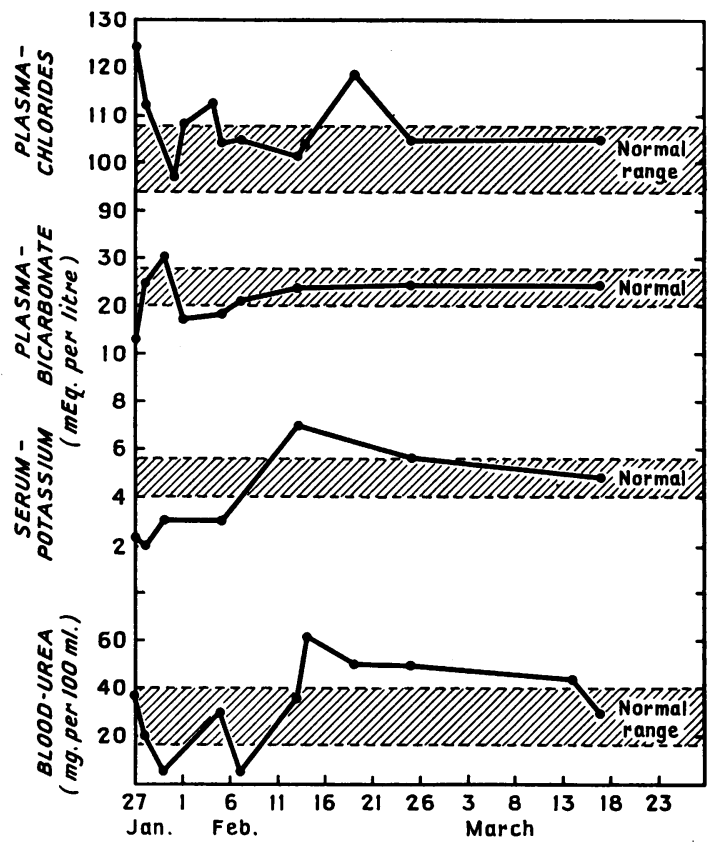

Fig. 2.-Case 2. Blood chemistry. On admission there was a marked hyperchloraemic acidosis with hypokalaemia. This was followed by an alkalosis for a short period. The first raised blood urea and serum potassium may have been due to an episode of dehydration combined with the giving of excess oral potassium chloride. The high blood urea values which persisted may well have been due to a high protein intake, as the urea clearance was normal when the blood urea was still raised.
After treatment with sodium lactate a slight alkalosis developed (plasma bicarbonate 57.6 vols. $\mathrm{CO}_{2} \%$ or $25.7 \mathrm{mEq}$. per 1.) which had increased on the fifth day (plasma bicarbonate 67.2 vols. $\mathrm{CO}_{2} \%$ or $30 \mathrm{mEq}$. per 1 .) and was accompanied by oedema. The hypokalaemia found on admission persisted for 12 days. No additional potassium was given during the first 12 hours while there was still considerable dehydration. The changes in blood urea were carefully followed throughout the illness. After the initial normal value on admission the level fell to $20 \mathrm{mg}$. \% on the second day and to $6 \mathrm{mg}$. \% three days later. At this stage the protein intake was very small as most of the fluid requirement was being given intravenously. By the nineteenth day the blood urea had risen to $61 \mathrm{mg}$. \% ; this rise coincided with a rise in the protein intake and was not associated with dehydration nor did it appear that glomerular insufficiency was responsible, as a urea clearance five days later was quite normal (94.1\% of average normal) when the blood urea was still $50 \mathrm{mg}$. \%. It was only at the end of the seventh week that the blood urea finally became normal.

Urinary Findings (Table 6 and Fig. 3) and Renal Functions (Table 4). The routine examination of the urine on admission did not show any unusual features apart from a slight proteinuria (40 $\mathrm{mg}$. \%) and a few red blood cells and granular casts on microscopy. These findings are not uncommon during a state of dehydration (see Table 7). It was not until the fifth day that any unusual degree of renal damage was suspected. At this time there was definite polyuria in the presence of slight dehydration, when oliguria would normally be expected. The urine was found to be dilute (S.G. 1,007) with a $p H$ of $7 \cdot 5$, a protein content of $50 \mathrm{mg}$. $\%$ and a chloride content of $580 \mathrm{mg}$. \% as $\mathrm{NaCl}(99 \cdot 1 \mathrm{mEq}$. per 1.). The slightly alkaline urine was not considered remarkable in view of the alkalosis, but the levels of chloride in the urine and serum were almost identical, indicating failure to absorb the chloride contained in the glomerular filtrate (Fig. 3). Next day the urine was examined by chromatography and a marked amino-aciduria was found. There was now considerable proteinuria (reported as ' ++ ' on the boiling test) and a slight rise in the specific gravity to 1,012 (no allowance for the proteinuria was made). The $p \mathrm{H}$ was now 8.3 in spite of a moderate acidosis, and the urinary chloride level remained almost the same as that in the serum (urinary chlorides $608 \mathrm{mg} . \%$ as $\mathrm{NaCl}$. or $104 \mathrm{mEq}$. per 1., serum chlorides $632 \mathrm{mg}$. \% as $\mathrm{NaCl}$. or $108 \mathrm{mEq}$. per 1.). The urinary urea was very low (190 mg. \%). There was thus evidence of failure of reabsorption of water and chloride (Fig. 6) (and presumably of sodium also) and of amino acids. There was also a failure of acidification of the urine. The significance of the proteinuria will be discussed later.

Recovery occurred rapidly. By the ninth day the specific gravity of the urine had risen to 1,026 and the chloride content had fallen to $465 \mathrm{mg}$. \% as $\mathrm{NaCl}$ (79.5 mEq. per 1.). On the nineteenth day the urinary urea concentration had risen to $1,440 \mathrm{mg}$. $\%$ and the $p \mathrm{H}$ had fallen to $6 \cdot 4$, though there was still a considerable degree of proteinuria (450 mg. \%). Six days later a urea 
TABLE 6

URINE TESTS: CASE 2

\begin{tabular}{|c|c|c|c|c|c|c|c|c|c|}
\hline Date & $\begin{array}{l}\text { Reaction } \\
\text { or } p \mathbf{H}\end{array}$ & $\begin{array}{l}\text { Specific } \\
\text { Gravity }\end{array}$ & $\begin{array}{c}\text { Urea } \\
\text { (mg. \%) }\end{array}$ & $\begin{array}{l}\text { Chloride } \\
\text { (mg. \% as } \mathrm{NaCl} \text { ) }\end{array}$ & $s_{(\mathrm{mEq} . / 1 .)}$ & Protein & $\begin{array}{r}\text { Amino } \\
\text { Acids }\end{array}$ & Deposit & Remarks \\
\hline 27.1 .52 & $5 \cdot 0$ & - & - & 911 & $155 \cdot 7$ & 40 & - & $\begin{array}{l}\text { 1-10 R.B.C. } \\
\text { per H.P.F. }\end{array}$ & $\begin{array}{c}\text { Small 'concentrated ' } \\
\text { specimen }\end{array}$ \\
\hline 30.1 .52 & Alkaline & - & - & - & - & 50 & - & $\begin{array}{l}\text { 5-10 R.B.C. } \\
\text { per H.P.F. }\end{array}$ & Alkalotic \\
\hline 31.1 .52 & $7 \cdot 5$ & 1,007 & 240 & 580 & $99 \cdot 1$ & - & - & - & Alkalotic \\
\hline 1.2 .52 & $8 \cdot 3$ & 1,012 & 190 & 608 & $104 \cdot 0$ & ++ & ++ & - & Acidouc \\
\hline 3.2 .52 & $7 \cdot 3$ & 1,005 & - & 436 & $74 \cdot 5$ & ++ & \pm & - & Acidotic \\
\hline 4.2 .52 & $6 \cdot 8$ & 1,026 & - & 465 & $79 \cdot 5$ & ++ & + & - & Acidotic \\
\hline 14.2 .52 & $6 \cdot 4$ & 1,012 & 1,440 & 262 & $44 \cdot 8$ & 4.50 & - & Nil & \\
\hline 19.2 .52 & $6 \cdot 4$ & 1,010 & 900 & 360 & $61 \cdot 5$ & 80 & - & Nil & \\
\hline 25.2 .52 & $6 \cdot 5$ & 1,014 & 1,450 & 474 & $81 \cdot 0$ & 100 & - & - & \\
\hline 14.3 .52 & - & 1,006 & - & 238 & $40 \cdot 7$ & 20 & - & - & \\
\hline 17.3 .52 & Alkaline & - & - & - & - & 20 & - & Nil & \\
\hline 19.3.52 & - & - & - & - & - & - & Nil & - & \\
\hline
\end{tabular}

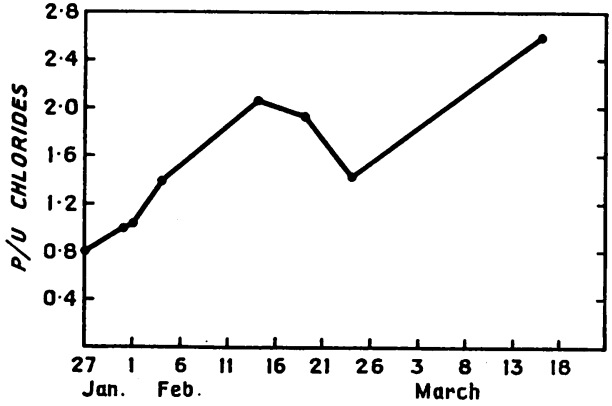

Fig. 3.-Case 2. During the first five days after admission the ratio of plasma chloride levels to those in the urine $(P / U)$ remained in the region of one, indicating the passage of a urine similar in composition

to the glomerular filtrate. With recovery the $\mathrm{P} / \mathrm{U}$ ratio rose.

clearance of $94 \cdot 1 \%$ of average normal (Table 4) was obtained. The proteinuria continued for another week (200 mg. \%) but later specimens of urine showed only traces of protein $(20 \mathrm{mg}$. \%) and were normal in every other respect.

Comment. This child was very ill on admission to hospital and initial treatment was concerned with the dehydration and abdominal distension; these aspects of the case have been considered more fully elsewhere (Schlesinger, Payne and Black, 1955). Examination of the urine from the fifth day onwards showed a definite degree of tubular damage, which rapidly improved. Though it was not possible to test all the functions of the renal tubules it was clear that there was impairment of $\mathrm{H}$-ion exchange and of the reabsorption of water, chlorides and amino- acids. Proteinuria was considerable and persisted for longer than any of the other urinary abnormalities. By the twenty-fourth day a urea clearance gave a normal result and complete clinical recovery appeared to have taken place.

Retrospective Survey (Table 7). During a survey of potassium metabolism in gastro-enteritis (Schlesinger et al., 1955) a record was made of all cases showing significant urinary abnormalities. Routine examination of the urine was done as soon after admission as possible and consisted of culture, microscopy and estimation of protein. Only those cases with a proteinuria of $\mathbf{4 0} \mathrm{mg}$. \% or more have been considered, but it was noticed that traces of protein (less than $40 \mathrm{mg}$. \%) and a few granular casts were very frequently present if the urine were examined immediately after admission, when dehydration was at its maximum. Of 653 cases reviewed, 21 had proteinuria of $40 \mathrm{mg}$. \% or more. From Table 7 it appears that there is a rough correlation between the clinical estimate of dehydration and the amount of protein in the urine, though it must be emphasized that the cases recorded in Table 7 are only a few of those admitted in comparable states of dehydration. In most of the 21 cases the proteinuria was found on the first or second day and persisted for two to three days only. In a few instances it continued for longer (M.G. 12 days, B.W. 15 days, Mary R. 25 days).

In this group there were four fatal cases, all of which showed some histological changes in the nephron. 
(1) G.T., age 6 weeks. Admitted with a history of four weeks of diarrhoea and vomiting. On the sixth day the urine showed $40 \mathrm{mg}$. \% of protein and a few leucocytes. Death on the fourth day probably from hyperkalaemia. At autopsy the kidneys were congested and the convoluted tubular epithelial cells were somewhat swollen.

(2) R.F., age 1 year. Admitted with a three-week history of vomiting. On admission the urine was normal, but by the twelfth day a trace of protein was present, with numerous red cells and a few leucocytes. A week later, the protein had increased to $200 \mathrm{mg}$. $\%$ and then gradually decreased. The red cells decreased in number but the number of epithelial cells increased until death at 24 days. At autopsy the kidneys contained numerous pyaemic abscesses. There were also widespread degenerative changes involving the whole length of the tubules, including the collecting tubules. Death was due to pyaemia.

(3) R.B., age 4 months. Admitted with diarrhoea and vomiting for one week. The urine was normal on admission but by the fifteenth day contained $100 \mathrm{mg} . \%$ of protein, numerous epithelial cells and some leucocytes and red cells. Death on the twenty-eighth day was due to osteomyelitis and septicaemia. At autopsy the glomeruli were swollen and Bowman's capsules and the tubules were filled with an albuminous fluid. The tubular epithelial cells were vacuolated and the tubules were dilated throughout their length.

(4) M.R., age 4 months. Admitted with a three-day history of diarrhoea and vomiting. On the third day after admission the urine contained $100 \mathrm{mg} . \%$ of protein, a moderate number of epithelial cells and a few leucocytes, red cells and granular casts. Death occurred next day with oedema and fits. The blood urea on the day before death was $148 \mathrm{mg}$. \% but no oliguria was noted at any time. At autopsy the kidneys were congested and there was interstitial oedema. Bowman's capsules contained an albuminous fluid. The convoluted tubules showed evidence of severe damage and were filled with an albuminous fluid and red cells. The collecting tubules showed similar changes.

TABLE 7

PROTEINURIA IN GASTRO-ENTERITIS

\begin{tabular}{|c|c|c|c|c|c|c|c|c|c|}
\hline Name & Sex & Age & $\begin{array}{l}\text { Degree of } \\
\text { Dehydration }\end{array}$ & $\begin{array}{l}\text { Maximum } \\
\text { Blood Urea } \\
(\mathrm{mg} . \%)\end{array}$ & $\begin{array}{l}\text { Maximum } \\
\text { Proteinuria } \\
\text { (mg. \%) }\end{array}$ & R.B.C. & W.B.C. & Casts & Comments \\
\hline S.L. & $F$ & $15 / 12$ & +++ & N.R. & 800 & 0 & $\therefore$ & Cellular + & \\
\hline R.F. & $\mathbf{F}$ & $1 \mathrm{yr}$ & $+4+$ & N.R. & 200 & Occas. & + & $\begin{array}{l}\text { Occas. } \\
\text { granular }\end{array}$ & Died \\
\hline M.R. & $\mathbf{M}$ & $4 / 12$ & +1 & 160 & 100 & Occas. & Occas. & $\begin{array}{l}\text { Occas. } \\
\text { granular }\end{array}$ & Died \\
\hline J.C. & $\mathbf{M}$ & $6 / 12$ & 4 & 44 & 100 & 0 & Occas. & Granular + & \\
\hline R.B. & $\mathbf{M}$ & $4 / 12$ & + & N.R. & 100 & Occas. & $\begin{array}{c}5-10 \\
\text { E.C. }+\end{array}$ & 0 & Died \\
\hline J.M. & $\mathbf{M}$ & $6 / 12$ & + & 80 & 100 & 0 & 1-2 E.C. & Occas. & \\
\hline Mary R. .. & $\mathrm{F}$ & $10 / 52$ & + & N.R. & 100 & 0 & 0 & 0 & \\
\hline E.T. & $\mathbf{M}$ & $2 / 12$ & $+\therefore$ & N.R. & 70 & 0 & $4-5$ & 0 & \\
\hline I.L. & $\mathbf{M}$ & $3 / 52$ & + & 38 & 70 & Occas. & Occas. & 0 & \\
\hline A.T. & $\mathbf{M}$ & $4 / 12$ & + & N.R. & 70 & 0 & 0 & Occas. & \\
\hline R.P. & $\mathbf{M}$ & $6 / 12$ & $\therefore$ & N.R. & 65 & 0 & 0 & Granular + & \\
\hline J.C. & $\mathbf{M}$ & $7 / 52$ & 0 & N.R. & 60 & 0 & 0 & Occas. & \\
\hline W.M. & $M$ & $5 / 12$ & + & 22 & 50 & 0 & - & Occas. & \\
\hline B.W. & $\mathrm{F}$ & $4 / 12$ & $\therefore$ & 34 & 48 & 0 & 0 & 0 & \\
\hline C.H. & $\mathbf{M}$ & $2 / 12$ & ++ & 148 & 45 & 0 & 0 & 0 & \\
\hline M.V & $\mathbf{M}$ & $7 / 12$ & $+\cdots$ & 14 & 45 & 0 & 0 & 0 & \\
\hline M.G. & $\mathbf{F}$ & $2 / 12$ & $\therefore$ & N.R. & 45 & 0 & Occas. & Occas. & \\
\hline M.L. & $\mathbf{M}$ & $4 / 52$ & 4 & 35 & 40 & 0 & 0 & 0 & \\
\hline G.T. & $\mathbf{M}$ & $6 / 52$ & + & 83 & 40 & 0 & Occas. & 0 & Died \\
\hline D.F. & $M$ & $4 / 52$ & $t+$ & 31 & 40 & $15-20$ & 5 & 0 & \\
\hline R.G. & $F$ & $7 / 12$ & + & N.R. & 40 & Occas. & Occas. & 0 & \\
\hline
\end{tabular}


Comment. Of the four cases G.T. showed the least histological changes and death was probably due to hyperkalaemia. The other three cases showed varying degrees of proteinuria with epithelial cells, which probably indicated desquamation of the tubular epithelium.

It is of interest that Cases R.B. and M.R. showed an albuminous fluid in Bowman's capsules, which apart from the possibility of reflux, suggested that the protein in the urine originated in an increased permeability of the capsular epithelium.

\section{Discussion}

Acute tubular necrosis may vary greatly in severity. In mild cases there is suppression of urine for only a few hours without the blood urea rising above normal (Bull, Joekes and Lowe, 1955). Nevertheless, the diuretic phase even in such cases requires careful management if dehydration and electrolyte depletion are to be avoided. When the anuria or oliguria is of short duration the patient may pass into the diuretic phase without renal damage being suspected. This is particularly liable to happen in infantile gastro-enteritis where attention is focused on the gastro-intestinal tract. If the diagnosis is suspected when the diuretic phase has already developed (see Case 2) a timed specimen of urine should be collected for as long a period as possible in order that an estimate of the urinary output can be made. The specific gravity of the urine should be measured and also the urinary chloride content, as the chloride levels in the urine or serum tend to be approximately the same during the diuretic phase, the urine coming to resemble a glomerular filtrate. Other tubular functions are also affected. The $\mathrm{H}$-ion exchange mechanism appears to be damaged so that the urine tends to remain constantly neutral or slightly alkaline even in the presence of an acidosis. Transient glycosuria and amino-aciduria sometimes occur (Burch and Ray, 1949; Bull, Joekes and Lowe, 1950; Lowe, Moodie and Thomson, 1954; Carré and Squire, 1956), but normal blood levels should be demonstrated before these findings can be taken as unequivocal evidence of tubular damage. Of the two cases described here, polyuria was found in Case 2, failure of acidification of the urine and amino-aciduria in both cases, and glycosuria in Case 1. In Case 2 there was also the tendency for the urinary chloride levels to approximate to those of the serum. Proteinuria persisted until the fifth week in both cases. The significance of proteinuria in tubular necrosis has not been determined, but it has been recognized in many papers on the subject
(Swan and Merrill, 1953; Lowe et al., 1954; Wagner, 1954; Bull et al., 1955). The proteinuria could be caused by a defect in tubular reabsorption of a normal load from the glomerular filtrate, assuming that the glomerular filtrate in man does indeed contain protein (Oliver, 1948; Rather, 1952; Sellers, Griggs, Marmorston and Goodman, 1954; Hardwicke and Squire, 1955). Alternatively, if the amount of protein in the glomerular filtrate were greatly increased by altered permeability of the glomerular membrane the mechanism for tubular reabsorption of protein could become overloaded, and proteinuria would result. There is good evidence of glomerular damage in the early stages of the syndrome of tubular necrosis (Bull et al., 1950; Oliver et al., 1951) and it is possible that an abnormal permeability to plasma proteins may persist for some time after all the tests of glomerular filtration rate have returned to normal (see Cases 1 and 2). Such a mechanism of abnormal permeability has been suggested in tubular necrosis (Oliver et al., 1951) and in nephrosis (Hardwicke and Squire, 1955). At present there is no evidence as to the exact cause of the proteinuria in tubular necrosis, but further information might be obtained from electrophoresis of the urinary proteins, as in the studies already made in other renal conditions (Rigas and Heller, 1951; Wolvius and Verschure, 1957). Whatever the cause of the proteinuria in tubular necrosis, its presence in a patient recovering from severe shock or dehydration is a good indication to investigate the renal functions more fully. It has been recently pointed out, however, that in severe potassium deficiency many of the functions of the tubule are affected and that proteinuria may occur (Milne, Muehrcke and Heard, 1957), so that potassium deficiency must always be considered as a contributory or even the sole cause of tubular dysfunction in the presence of electrolyte disturbances. Milne et al. (1957) have pointed out that defective function of the proximal tubule is rare in potassium deficiency and therefore glycosuria and amino-aciduria are unlikely to occur in such circumstances. The cellular content of the urine in tubular necrosis has received only passing mention in a few of the descriptions (Burch and Ray, 1949; Swann and Merrill, 1953). In Case 1 there was a considerable number of epithelial cells in the urine from the thirty-seventh day (and probably earlier) until the forty-ninth day. In view of the histological findings in such cases it is probable that these cells represent epithelium shed from the necrotic tubules. Further investigation of the cellular output by improved methods (Houghton and Pears, 1957) may help to evaluate the frequency with which minor degrees of 
tubular damage occur in states of shock or dehydration.

The management of adults with tubular necrosis has been ably covered by Bull and his co-workers (Bull, 1955; Bull et al., 1955). Carré and Squire (1956) have described the treatment of three children with tubular necrosis and there is little to add to their general scheme of treatment. However, when diarrhoea is present, variable and usually unknown amounts of fluid and electrolytes are lost in the stools so that analysis of the urine no longer gives an adequate guide to the daily requirements. Probably the best control under such circumstances is by daily weighing and repeated estimations of the blood chemistry. In the two cases presented here the replacement of electrolytes was not difficult. In Case 1 the acidosis was easily rectified by sodium citrate-citric acid mixture and the hypokalaemia by potassium chloride. In Case 2 the fluid intake had to be increased during the diuretic phase, but there was no chloride depletion, probably because the fluid supplied at this time was in the form of half-strength Hartmann's solution which contains $0.3 \%$ of sodium chloride. In this case also the serum potassium was kept normal without difficulty in spite of the diarrhoea. Recovery was rapid in both cases and normal glomerular filtration rates were obtained in Case 1 in the sixth week of the illness and in Case 2 in the fourth week. Though all tubular functions were not tested separately, there appeared to be recovery of all the previously defective renal functions. The subsequent progress of these two cases, from the renal point of view, was normal.

\section{Summary}

Renal tubular damage is described in infantile gastro-enteritis. The importance of detecting this complication is emphasised.

I wish to thank Dr. B. E. Schlesinger and Dr. W. W. Payne for their help in the preparation of this paper, and Dr. Martin Bodian for his reports on the histology.

REFERENCES

Bull, G. M. (1955). Lancet, 1, 731, 777

Joekes, A. M. and Lowe, K. G. (1950). Clin. Sci., 9, 379.

- -,-1 (1955). Lancet, 2, 1152.

Burch, G. E. and Ray, C. T. (1949). Ann. intern. Med., 31, 750

Calcagno, P. L. and Rubin, M. I. (1951). Pediatrics, 7, 328.

Carré, I. J. and Squire, J. R. (1956). Arch. Dis. Childh., 31, 512

Doxiadis, S. A. (1947). Ibid., 22, 180.

Hardwicke, J. and Squire, J. R. (1955). Clin. Sci., 14, 509.

Houghton, B. J. and Pears, M. A. (1957). Brit. med. J., 1, 622

Jonsson, B. (1951). Acta paediat. (Uppsala), 40, 401.

Kaplan, S. A. and Fomon, S. J. (1953), A.M.A. Amer. J. Dis. Child.,

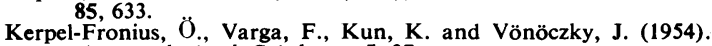
Acta med. Acad. Sci. hung., 5, 27.

Lowe, K. G., Moodie, G. and Thomson, M. B. (1954). Clin. Sci., 13, 187.

Milne, M. D., Muehrcke, R. C. and Heard, B. E. (1957). Brit. med. Bull., 13, 15

Oliver, J. (1948). J. Mt Sinai Hosp., 15, 175

- MacDowell, M. and Tracy, A. (1951). J. clin. Invest., 30, 1305.

Pratt, E. L. (1948). Amer. J. Dis. Child., 76, 14

Rather, L. J. (1952), Medicine (Baltimore), 31, 357.

Riddell, H. I. (1951). J. Urol. (Baltimore), 65, 513.

Rigas, D. A. and Heller, C. G. (1951). J. clin. Invest., 30, 853.

Schlesinger, B. and Welch, R. G. (1952). Gt Ormond Str. J., No. 3, p. 14.

_- Payne, W. and Black, J. (1955), Quart. J. Med., 24, 33

Sellers, A. L., Griggs, N., Marmorston, J. and Goodman, H. C. (1954). J. exp. Med., 100, 1. Swann, R. C. and Merrill, J. P. (1953). Medicine (Baltimore), 32,

Van Slyke, D. D. (1954). Ann. intern. Med., 41, 709.

Wagner, J. (1954). Gt Ormond Str. J. No. 7, p. 66.

Wolvius, D. and Verschure, J. C. M. (1957). J. clin. Path., 10, 80

Zuelzer, W. W., Charles, S., Kurnetz, R., Newton, W. A. and Fallon, R. (1951). A.M.A. Amer. J. Dis. Child., 81, 1. 